\title{
Two sorts of natural theology
}

\author{
Martin Jakobsen
}

\begin{abstract}
Usually, natural theology is understood as the project of providing arguments for the existence of God. This project is endorsed by Moreland and Craig. McGrath, on the other hand, says that this project fails. In the first part of this article, I show how McGrath's dismissal of arguments for the existence of God follows from his view of natural theology. In the second part, I argue that McGrath's natural theology contains an accurate critique of Moreland and Craig's way of doing natural theology, a critique that exposes two major problems in their treatment of the moral argument for the existence of God. In the third part, I propose a way of providing arguments for the existence of God that avoids the problems pointed out by McGrath, namely a way of arguing that seek to show how theology may improve a certain non-theistic understanding of a natural phenomenon.
\end{abstract}

\section{Providing arguments for the existence of God}

Some theologians hold that natural theology can provide sound arguments for the existence of God. Two of them are J. P. Moreland and William Lane Craig. Both Moreland and Craig are theologians and professors of philosophy at Biola University, and together they have edited The Blackwell Companion to Natural Theology. In this companion, they uphold a common understanding of natural theology, ${ }^{1}$ namely natural theology as "the branch of theology that seeks to provide warrant for belief in God's existence apart from the resources of authoritative, propositional revelation." 2 The companion treats several natural phenomena, such as moral values, consciousness, and the beginning of the universe, and takes each of them to provide an independent argument for the hypothesis that there is a God. According to the two editors, natural theology can provide arguments that leads "logically to the conclusion that God exists", and these arguments should convince everyone, not only believers.

\footnotetext{
${ }^{1}$ Chignell and Pereboom, "Natural Theology and Natural Religion"; McGrath, The Open Secret, 15.

${ }^{2}$ Craig and Moreland, The Blackwell Companion to Natural Theology, ix.

${ }^{3}$ Moreland and Craig, Philosophical Foundations for a Christian Worldview, 494.
} 
Others are reluctant to say that natural theology can provide sound arguments for the existence of God. One of them is Alister McGrath, professor of science and religion at the University of Oxford. McGrath presents another sort of natural theology, namely natural theology understood as "the ability to perceive "heaven in the ordinary". When McGrath writes "the ordinary" he refers to the world, saying that there is only one world, one reality, in which both theists and atheists live. However, atheists and theists see the world differently. How can people see the world differently when they look at the very same world? Namely because seeing is an active process where one is linking sensory input to one's existing understanding of the world. ${ }^{5}$ As people have different understandings of the world, they see the world differently. Natural theology, then, consists in seeing nature in one particular way, namely a Christian way. As such, McGrath sets out to "reformulate natural theology" so that it is conceived of as a theological activity, as a Christian or a Trinitarian way of looking at nature. ${ }^{6}$

McGrath considers the sort of natural theology endorsed by Moreland and Craig as the classical way of doing natural theology. McGrath rejects classical natural theology, and his main reason for this is that classical natural theology presupposes that everyone sees nature in the same way. ${ }^{7}$ Since there is no universal way of seeing nature, classical natural theology will for once always have an element of circularity, and secondly not be able to establish premises that constitute ground for a proof. Now, let's take a closer look at these two points.

Why does McGrath think classical natural theology involves circularity? First, he argues that there is an "intellectual ambiguity of nature". It is not obvious how nature should be interpreted. Nature itself does not determine its own interpretation, which means that nature has to be unlocked using a key that nature does not provide. ${ }^{8}$ Second, this ambiguity naturally gives rise to a number of ways of seeing nature, and not all ways of seeing nature reveal the divine. So, if nature is to reveal the divine, then it has to be seen in a specific way, namely through interpretive framework of the Christian faith. ' It is worth noting how the title of one of McGrath's books, The Open Secret, illustrate this point. The Open Secret is a phrase that the Swiss theologian Karl Barth uses when describing God's revelation. ${ }^{10}$ The notion expresses that even though God has openly revealed himself for all to see, the revelation is a secret in the sense that it is not at all

\footnotetext{
${ }^{4}$ McGrath, The Open Secret, 79, 115. For numerous other conceptions of natural theology, see McGrath, Re-Imagining Nature, 11-25.

5 McGrath, The Open Secret, 73-75.

${ }^{6}$ McGrath, Re-Imagining Nature, 171. See especially McGrath, The Open Secret, chap. 8; McGrath, Re-Imagining Nature, chap. 2. Although McGrath often qualifies his natural theology as Trinitarian natural theology, the trinity gets somewhat lost when he starts doing natural theology. God the creator has an important role when discussing classical theistic arguments, Jesus has a role in revealing how nature is to be seen (McGrath, Re-Imagining Nature, 69.), but the Spirit is hard to spot.

${ }^{7}$ McGrath, Re-Imagining Nature, 26. McGrath is also critical of doing natural theology "apart from the resources of revelation", which would mean that natural theology is no longer a part of Christian theology. He shows how both Barth and Brunner, in their famous debate, rejected such a natural theology. McGrath, 147.

${ }^{8}$ McGrath, The Open Secret, 2009, 3; McGrath, Re-Imagining Nature, 33.

${ }^{9}$ McGrath, The Open Secret, 73, 115.

${ }^{10}$ Barth, Church Dogmatics, 1956, IV.1:195; Barth, Church Dogmatics, 1960, III.2:316.
} 
obvious. ${ }^{11}$ To unlock the secret, we must see nature through the eyes of faith. As such, arguments claiming that nature reveals God will always involve circularity, as they will always presuppose a Christian interpretive framework.

McGrath is also dismissive of classical natural theology as it sets out to establish proofs for the existence of God. He understands "a proof" to be a demonstration of how the existence of God is "the only way of making sense of what is observed", and argues that it is impossible to establish such proofs. Now, nature is observed in many ways, through many interpretive frameworks. If we had a set of universal criteria for evaluating theories, criteria not dependent on any specific framework, then we would have the tools needed to evaluate the different frameworks and find the one that gives the best - possibly the correct - picture of the world. ${ }^{13}$ This conception of a universal set of criteria, or a universal rationality, lay at the heart of the enlightenment project and gave rise to the classical natural theology. ${ }^{14}$ However, says McGrath, this conception of rationality can no longer be maintained. There is no rational "view from nowhere." 15 McGrath draws upon the work of MacIntyre, arguing that there is no universal rationality, only competing and conflicting rationalities that are mediated through different traditions. ${ }^{16}$ The lack of a universal rationality means that one cannot evaluate competing interpretive frameworks from a rational "view from nowhere". If one were to compare frameworks, one would inevitably be judging other frameworks by the standards of one's own; other ways of seeing nature would be judged according to one's own way of seeing nature. But this would be a sort of criteriological imperialism, says McGrath, and would not be a fair treatment of other frameworks. ${ }^{17}$ So, in the absence of a framework-independent set of criteria which all interpretive frameworks could be judged upon, proofs for the existence of God are doomed to fail. ${ }^{18}$

\section{A theology of nature: resonance, not proofs}

These two considerations force us to reformulate natural theology, says McGrath. He holds that natural theology should be seen as the specific - and clearly theory-laden - Christian vision of the

\footnotetext{
${ }^{11}$ Barth, Church Dogmatics, 1957, II.1:55.

12 McGrath, The Open Secret, 16.

${ }^{13}$ McGrath, Scientific Theology, Volume 2, 58.

14 McGrath, Re-Imagining Nature, 31.

${ }^{15}$ McGrath, 27. This is a reference to Thomas Nagel, whom McGrath says has shown that every viewpoint is a view from somewhere. However, Nagel's point is that one must see the world "both from nowhere and from here". Nagel, The View From Nowhere, 68.

${ }^{16}$ McGrath, Scientific Theology, Volume 2, 64; McGrath, Re-Imagining Nature, 32.

${ }^{17}$ McGrath can be taken to suggest that competing framework can be evaluated according to how coherent they are (McGrath, Scientific Theology, Volume 2, 75.). However, he does not suggest using coherence as a criterion for evaluation in his other books on natural theology, but rather states that there is no single rationality upon which all frameworks can be evaluated. See McGrath, The Open Secret, 168; McGrath, A Fine-Tuned Universe, 15-16; Alister E. McGrath, The Science of God, 90; McGrath, Re-Imagining Nature, 2, 152.

${ }^{18}$ McGrath, Scientific Theology, Volume 2, 58. It seems like McGrath takes this point further than MacIntyre, whose work McGrath draws upon. MacIntyre holds that some phenomenon can only be explained, or can be best explained, in one framework and not in another. When this is the case, this phenomenon will give you a reason to leave the old framework and embrace the new one. MacIntyre, Whose Justice? Which Rationality?, 363-65.
} 
world, a vision that allows us to re-imagine nature; see it in a new way; see it in a Christian way. ${ }^{19}$ This Christian way of seeing reality is neither naturally acquired nor naturally endorsed. ${ }^{20}$ With a brief reference to human sinfulness, McGrath describes how human nature is haunted by an inability to see the world as it really is. ${ }^{21}$ However, we can be transformed so that we see the world anew, and this transformed view of reality is mediated through the church as a community of interpretation. ${ }^{22}$ This Christian interpretation of the world gives an "expanded vision of reality" ${ }^{23}$ and enable us to "grasp reality at a deeper level". ${ }^{24} \mathrm{McGrath}$ 's natural theology takes the opposite direction of the classical natural theology. While the classical natural theology uses our view of the world to inform us about theology, McGrath uses theology to inform our view of the world. As such, his project might be better described as "theology of nature" than "natural theology". ${ }^{25}$ So, does McGrath's sort of natural theology provide room for theistic arguments?

McGrath clearly states that natural theology cannot provide theistic proofs, and that one cannot deduce the characteristics of God from nature. ${ }^{26}$ Now, "proof" and "deduction" are quite strong terms. A quite influential approach to natural theology, an approach that McGrath is aware of, ${ }^{27}$ is to argue that aspects of nature provide evidential support for theism, not proofs. Philosopher Richard Swinburne, for instance, argues that aspects of reality such as the beginning of the universe and our moral awareness makes theism more likely than atheism, but not that it proves theism to be true. ${ }^{28}$ So, does McGrath's natural theology allow room for any kind of theistic arguments? In earlier works, he has been quite dismissive, writing that there is "no question" of a classical natural theology providing a gateway to a theistic system. ${ }^{29}$ However, in his later work he holds that his Cristian natural theology is able to "accommodate and position" the classical natural theology. ${ }^{30}$ He illustrates this accommodating with a scientific analogy. Just as quantum mechanics is a more fundamental theory than classic mechanics, and qualifies classic mechanics, a Christian theology of nature is more fundamental than a classical natural theology, and is able to accommodate it, qualify it, and define its scope. ${ }^{31} \mathrm{McGrath}$ qualifies classical natural theology in the following sense: Natural theology is not about providing proofs, it is about interpreting nature in light of the received Christian tradition. And when this interpretation makes sense of

\footnotetext{
${ }^{19}$ McGrath, Re-Imagining Nature, 8.

${ }^{20}$ McGrath, 55.

${ }^{21}$ McGrath, 43, 50.

22 McGrath, 55, 100.

${ }^{23}$ McGrath, 155.

24 McGrath, 43.

${ }^{25}$ As also pointed out by Holder, The Heavens Declare, 174. McGrath writes that the Latin phrase that he often uses, Theologia Naturalis, could be translated either way. McGrath, Re-Imagining Nature, 12.

${ }^{26}$ McGrath, A Fine-Tuned Universe, 40, 218.

${ }^{27}$ McGrath, Re-Imagining Nature, 119.

${ }^{28}$ Swinburne, The Existence of God. See also John Polkinghorne, "Where Is Natural Theology Today?”; Evans, Natural Signs and Knowledge of God.

${ }^{29}$ McGrath, The Open Secret, 5. See also Alister E. McGrath, The Science of God, 88-89; McGrath, A Fine-Tuned Universe, 14.

${ }^{30}$ McGrath, Re-Imagining Nature, 36.

${ }^{31}$ McGrath, 36-37, 130.
} 
how we experience the world, there can be said to be "a resonance" between this Christian framework and what is observed, which gives the framework credibility. ${ }^{32}$

Does this resonance give us a reason to accept a Christian framework? It is clear that McGrath takes this resonance to make a Christian framework more plausible to those already committed to it. McGrath even describes the agenda of Christian natural theology as increasing the commitment to a Christian framework. ${ }^{33}$ It is not entirely clear, however, whether the resonance provides a reason to accept a theistic framework only for those already committed to such a framework, or if it also provides a reason to accept a theistic framework for those who do not see the world through such a framework.

At times, McGrath implies that the resonance can provide everyone with a reason to accept a theological framework. He frequently turns to the notion of abduction, writing that abduction is characteristic of natural theology. ${ }^{34}$ Abduction is a method of argumentation that seeks out the best explanation of a certain matter of fact. ${ }^{35}$ By linking abduction to natural theology, McGrath writes that natural theology can show that a Christian framework offers the best explanation of our observations. ${ }^{36}$ This enables him to say that the resonance between what is observed and the Christian vision of reality "can be seen as an indication of both its truth and its trustworthiness", ${ }^{37}$ and to write about how he himself came to be a Christian on the basis that the Christian faith "made far more sense of what I saw around me and experienced within me" than the atheist alternatives he considered. ${ }^{38}$

However, demonstrating resonance does not amount to several independent arguments for the existence of God. Take for instance McGraths treatment of the fine-tuning argument for the existence of God. ${ }^{39} \mathrm{He}$ takes this argument to be "insignificant" when treated as one isolated argument for theism. ${ }^{40}$ All the fine-tuning argument shows is that the finely tuned physical

\footnotetext{
${ }^{32}$ McGrath, 40; McGrath, A Fine-Tuned Universe, 218.

${ }^{33}$ McGrath, The Open Secret, 234.

${ }^{34}$ McGrath, A Fine-Tuned Universe, 218; McGrath, The Open Secret, 244; McGrath, Re-Imagining Nature, 178.

${ }^{35}$ For McGrath on abduction, see McGrath, A Fine-Tuned Universe, 42-49. See also Lipton, Inference to the Best Explanation, which McGrath often refers to. In The Open Secret, McGrath seems to conflate the notion of interpretation and the notion of explanation, as he uses the exact same criteria for evaluating explanations and interpretations. McGrath, The Open Secret, 170. In Re-Imagining Nature, McGrath seems to prefer the notion of interpretation, although he still uses the terms "explanatory advantages" and "best explanation". McGrath, ReImagining Nature, 94, 137, 177.

${ }^{36}$ McGrath, The Open Secret, 17; McGrath, A Fine-Tuned Universe, 45. Interestingly enough, McGrath seems to treat "argument for the best explanation" as universal criteria for evaluation that can be applied to all theories. See Holder, The Heavens Declare, 194.

${ }^{37}$ McGrath, Enriching Our Vision of Reality, 170. Notice his careful modifier: "can be seen as".

${ }^{38}$ McGrath's italics. McGrath, 110.

${ }^{39}$ Robin Collins argues that laws and constants of physics are fine-tuned for life, meaning that if these constants had been just slightly different, life would have been impossible. Given that there is no God, fine-tuning would be very unlikely. Given that there is a God, it would not be unlikely. Therefore, Collins argues, the fine-tuning supports theism. See Collins, “The Teleological Argument." McGrath treats the argument in McGrath, A Fine-Tuned Universe, 109-216.

${ }^{40}$ McGrath, "The Natural Sciences and Apologetics," 155.
} 
constants are consistent with a theistic framework, ${ }^{41}$ but the fine-tuning also seems consistent with other ways of viewing the world. ${ }^{42}$ However, if this argument is combined with many other arguments, as a kind of cumulative case, the sum becomes "richly suggestive" 43 as it shows that a Christian interpretation makes sense of the world as a whole. ${ }^{44}$

At other times, McGrath implies that the resonance does not provide everyone with a reason to accept a theological framework. It seems as if McGrath offers a room for classical natural theology with the one hand, but takes it away with the other. Let me present three such cases: First, on the one hand McGrath says that his conception of natural theology has a "considerable apologetic potential." ${ }^{\prime 4}$ On the other, he says that his natural theology only provides an internal confirmation of the Christian framework, ${ }^{46}$ meaning that the "insight that nature has the capacity to disclose God" is only available from the perspective of knowing God, and that those who do not know God "will never 'see' the true meaning of the open secret of nature." 47 Second, on the one hand McGrath says that natural theology has an audience both inside and outside the church. ${ }^{48}$ On the other, he says that one neither falls in love with a woman nor enter the womb of a church as a result of reasoning. ${ }^{49}$ Reasoning rather comes after the faith-act, as a

retrospective validation. ${ }^{50}$ So, the appeal of natural theology to the audience outside the church is not an appeal to reason. ${ }^{51}$ Third, McGrath will on the one hand often present two competing theories, such as Christian theism and naturalism, and say that the apologetic question is whether Christian theism provides the best explanation of a certain natural phenomenon. ${ }^{52}$ On the other, McGrath never says that the Christian framework gives the best explanation. He answers the apologetic question either by saying that the Christian framework is "clearly consistent" with the observation in question, ${ }^{53}$ or by saying that "For Christians, God is the best explanation" (my italics). ${ }^{54}$ Presumably, he answers the apologetic question in this way because that which needs explanation is always interpreted through some framework. To use one of McGrath's examples: A Christian observation of morality is best explained in a Christian framework, but when morality

\footnotetext{
${ }^{41}$ McGrath, The Open Secret, 243.

42 McGrath, 242.

${ }^{43}$ McGrath, "The Natural Sciences and Apologetics," 155.

${ }^{44}$ McGrath, Enriching Our Vision of Reality, 103. McGrath's italics.

${ }^{45}$ McGrath, The Open Secret, 16. McGrath writes that apologetics "seeks to show why it is reasonable, with the help of grace, to accept God's word as it comes to us through Scripture and the Church.” McGrath, "The Natural Sciences and Apologetics," 143. In Re-Imagining Nature, McGrath sees apologetics not as an act of providing arguments for the Christian faith but as removing obstacles and showing that the Cristian faith is not inconsistent. McGrath, ReImagining Nature, 174-75, 179.

${ }^{46}$ McGrath, A Fine-Tuned Universe, 218. See also McGrath, The Open Secret, 16 n36.

${ }^{47}$ McGrath, The Open Secret, 139.

${ }^{48}$ McGrath, Re-Imagining Nature, 131.

${ }^{49}$ McGrath, 143. McGrath quotes Crossman, The God That Failed, 15.

${ }^{50}$ McGrath, The Open Secret, 16.

${ }^{51} \mathrm{McGrath}$ will rather appeal to the imagination, which goes beyond a natural way of seeing nature, and to meaning. McGrath, Re-Imagining Nature, 43. He could ask the audience to "imagine a way of seeing things which proves to be deeply meaningful." McGrath, 131.

52 McGrath, Re-Imagining Nature, 86, 178; McGrath, The Open Secret, 234-35.

${ }^{53}$ McGrath, Re-Imagining Nature, 179. See also McGrath, The Open Secret, 243.

${ }^{54}$ McGrath, Enriching Our Vision of Reality, 105.
} 
is interpreted through other frameworks, morality seems to be best explained in other ways. ${ }^{55}$ These three cases are not examples of contradictions. Rather, I consider them to be examples of how McGrath takes a theology of nature to define the scope of classical natural theology, so that natural theology only provides reasons to accept a Christian framework for those who see nature "through the lens of the Christian revelation" ${ }^{56}$ - which is not a natural way of seeing but a "divinely transformed capacity of seeing". ${ }^{57}$

To sum up what has been said so far: McGrath holds that how we see nature and rationality is framework-dependent. The consideration that not everyone sees things the same way "seriously, probably fatally," undermine a classical natural theology ${ }^{58}$ However, classical natural theology can be saved by being incorporated into a Christian theology of nature, which qualifies natural theology and defines its scope. But the scope becomes somewhat narrow when considering what sort of reasons for accepting a Christian framework this natural theology provides. First, this qualified natural theology is not able to provide "proofs", not able to provide decisive reasons demonstrating that the only rational thing to do is to accept a Christian framework. Second, it is not able to provide a plurality of reasons given by single aspects of reality, such as one reason given by the fine tuning of the universe and another given by morality. It only provides one cumulative reason, given by how the Christian framework makes sense of reality as a whole. Third, as this cumulative reason can only be discerned from within the Christian community, and will only be valid within a Christian framework, it does not provide a reason for everyone but only for those who already accept the Christian framework. As such, we seem to have "a natural theology for the already converted." 59

McGrath's critique applied

So far, I have shown how McGrath critiques classical natural theology for overlooking that our view of nature is always framework-dependent, and how McGrath himself develops a natural theology that is attentive to this critique. What I will do now is to argue that McGrath's critique of classical natural theology is also an apt critique Moreland and Craig's natural theology. I will do so by applying the critique on their formulation of the moral argument for the existence of God, showing that their lack of attentiveness to our view of nature being framework-dependent results in two problems; namely that the argument ends up circular and the argument fails to be the proof that it aspires to be. Now, there are different ways in which one can formulate a moral argument. Moreland and Craig present and defend a fairly standard formulation. ${ }^{60}$ Craig has developed the argument in his own works, and he has popularised it through numerous debates. ${ }^{61}$ As philosopher Wes Morriston says: "No one has done more than William Lane Craig to push a

\footnotetext{
${ }^{55}$ McGrath, The Open Secret, 306-7.

${ }^{56}$ McGrath, Re-Imagining Nature, 131.

${ }^{57}$ McGrath, 43.

58 McGrath, 33.

59 A phrase used by Sarah Coakley in Coakley, Stories of Evolution, Stories of Sacrifice.

${ }^{60}$ Baggett and Walls, Good God, 100.

${ }^{61}$ A list of debates is found here: https://www.reasonablefaith.org/videos/debates (accessed January 10, 2018).
} 
certain type of moral argument for the existence of God." ${ }^{62}$ So, while there are many different formulations of the moral argument available, ${ }^{63}$ the fact that Craig has become one of the leading spokesmen of it makes it worthwhile to take a closer look at his formulation of the argument. Craig formulates the moral argument as follows: ${ }^{64}$

(1) If God did not exist, objective moral values and duties would not exist

(2) Objective moral values and duties do exist

(3) Therefore, God exists.

\section{Circular reasoning}

Let's first consider whom this argument sets out to convince. Craig holds that this argument provides everyone with a reason for believing in God, believers as non-believers. While this argument is not his favourite theistic argument, it is in his experience the most effective one in conversation with non-believers. ${ }^{65}$ Now, Craig sets out to show that objective ${ }^{66}$ moral values and duties entail that God exists. To accomplish this, he needs to establish his first premise, namely that such values and duties cannot exist unless God exists. Craig does so by pointing to our experience of morality, the common experience of there being certain things I ought to do as well as common moral beliefs such as the wrongness of rape and oppression. Our experience of morality tells us that some things are just wrong to do. This entails the notion of moral duties; duties which need to be imposed on us, which need to be grounded in a way that ensures their objectivity, and which we need to be held accountable for. ${ }^{67}$ If God exists, we see why there must be such duties: God's commands constitute moral obligations and God holds us accountable to them. ${ }^{68}$ But if God does not exist, "[t]he concept of morality loses all meaning". ${ }^{99}$ Without God, we cannot explain the objectivity of morality, we cannot explain why we ought to uphold these duties, and without an afterlife there is no ultimate accountability. Thus, he writes that " $[\mathrm{i}] \mathrm{n}$ a world without a divine lawgiver, there can be no objective right and wrong". ${ }^{70}$

\footnotetext{
${ }^{62}$ Morriston, "God and the Ontological Foundation of Morality," 15.

${ }^{63}$ For examples, see Evans, "Moral Arguments for the Existence of God."

${ }^{64}$ Craig, Reasonable Faith, 172; Moreland and Craig, Philosophical Foundations for a Christian Worldview, 495.

${ }^{65}$ Craig, Reasonable Faith, 194. One could question whether Craig gives a good defence of the claim that there are objective moral values and duties. However, since more and more philosophers accept the existence of objective moral values (Enoch, Taking Morality Seriously, 2011, 6; Finlay, "Normativity, Necessity and Tense," 57), I do not believe that the greatest weakness of his argument lies here.

${ }^{66}$ Craig sees moral values as objective in the sense that they are (constitutively) independent of what people believe. Craig, Reasonable Faith, 173.

${ }^{67}$ Moreland and Craig, Philosophical Foundations for a Christian Worldview, 490-96. See also Craig, "The Indispensability of Theological Meta-Ethical Foundations for Morality"; Craig, Reasonable Faith, 172-83; Craig and SinnottArmstrong, God?; Craig, "The Most Gruesome of Guests," 168-76.

${ }^{68}$ Note that it is not uncontroversial, in theistic ethics, to say that moral obligations are constituted by God's command. Theistic natural law ethicists would typically dispute it, as would a range of other theistic approaches, as Zagzebski who rather draws upon the virtues of God and the incarnation. Zagzebski, Divine Motivation Theory, pt. II. ${ }^{69}$ Craig, Reasonable Faith, 75.

${ }^{70}$ Craig, 75.
} 
It is when establishing this first premise that Craig does not give sufficient attention to the point that all facts are interpreted through some framework. McGrath pointed out that nature is ambiguous, and it is safe to say that the nature of morality is ambiguous as well. Craig interprets the nature of morality, or our experience of it, through the framework of a divine command theory. ${ }^{71}$ Accordingly, he sees morality to be about imposed duties, laws and accountability. However, as shown by for instance the Catholic philosopher G. E. M. Anscombe, it is not at all obvious that morality should be conceived of in terms of laws and obligations. The lawconception of morality, she says, has its roots in Christian thinking, in Christian and Jewish reflection upon the Torah. ${ }^{72}$ But there are other conceptions available. Anscombe suggests the Aristotelian tradition as a framework for interpreting morality. This interpretation would not see morality as implying moral laws and duties and accountability. It would instead see morality as implying virtues and the notion of human flourishing. ${ }^{73}$ An Aristotelian interpretation of morality would therefore not need a divine establisher and upholder of moral laws.

Above, McGrath pointed out that it is an example of circular reasoning to first interpret a matter of fact through a certain framework, and then use this specific interpretation to argue for the truth of this framework and the falsehood of other frameworks. But this seems to be what Craig is doing. Craig interprets morality in a Christian manner, seeing morality through the lens of a divine command theory and identifying it as being about moral laws and accountability. Then he argues that these features show that morality must have its foundation in a divine lawgiver. I agree that this specific interpretation of morality entails theism, but there are other feasible interpretations that do not. If morality is not seen to be about laws, no lawgiver is required. So, Craig's defence of the first premise fails to show that "without a divine lawgiver, there can be no right and wrong." ${ }^{74}$ All it shows is that a theistic view of morality implies theism, and that without a divine lawgiver there can be no divine command theory of morality. As such, he has not given everyone a reason to accept theism, only those who share his theologically rooted view of morality.

\section{Neglecting other interpretive frameworks}

Now, let's consider the force of the argument. Craig presents the moral argument as a deductive argument, and points out that if a deductive argument is logically valid, and its premises are true, "the conclusion follows inevitably". ${ }^{75}$ As such, the argument amounts to what McGrath calls "a proof". It gives us a decisive reason to accept the conclusion that God exists. ${ }^{76}$ What gives the

\footnotetext{
${ }_{71}$ Moreland and Craig, Philosophical Foundations for a Christian Worldview, 491; Craig, Reasonable Faith, 181-82.

72 Anscombe, "Modern Moral Philosophy," 5. See also Zagzebski, Divine Motivation Theory, 228-31.

73 Anscombe, "Modern Moral Philosophy," 18-19.

${ }^{74}$ Craig, Reasonable Faith, 75.

${ }^{75}$ Craig, 52, 195. "If we do think that objective moral values exist, then we shall be led logically to the conclusion that God exists." Moreland and Craig, Philosophical Foundations for a Christian Worldview, 494.

${ }^{76}$ Craig takes deductive arguments against the existence of God to have the same strength. He writes that if the logical version of the problem of evil were a sound argument, "God would not exist, case closed." (Moreland and Craig, Philosophical Foundations for a Christian Worldview, 542). In his many debates, Craig usually presents around five arguments for the existence of God. This might give the impression that he takes the arguments not to be decisive
} 
argument such categorical force is the categorical formulation of the first premise: no God, no morality. If we reformulate the first premise into McGrath's vocabulary, we could say that "the only way to make sense of moral values is within a theological framework." As shown above, Craig demonstrates that a theological framework makes good sense of morality. But has he shown that this is the only way of making sense of morality, as stated in the first premise? If other interpretive frameworks make sense of moral values, the first premise will fall.

Craig considers an alternative framework for interpreting morality, namely what he and Moreland calls an atheistic hypothesis, ${ }^{77}$ which Craig elsewhere specifies as a naturalistic hypothesis. ${ }^{78}$ The naturalistic hypothesis is understood as follows: Moral values are constituted by human preferences or desires. Human preferences have been heavily influenced by the evolutionary process. This means that the morally right action is the action that the evolutionary process has made us biased towards. ${ }^{79}$ Craig concludes that this naturalistic view of morality is not compatible with the view that moral values are objective. After all, if the evolutionary process had gone differently, our moral beliefs would have been different. ${ }^{80}$

I agree with Craig that such a naturalistic view of morality is incompatible with moral values being objective. However, this observation is not very interesting, nor is it significant to the construction of a moral argument. Why not? First, because most theories of morality that hold moral values to be constitutively dependent on human desires openly reject the kind of moral objectivity that Craig have in mind. ${ }^{81}$ Arguing that these desire-based naturalistic theories are incompatible with moral objectivism is therefore close to just stating the obvious. Second, arguing that moral objectivity is not compatible with this naturalistic view of moral values is not sufficient to show that objective moral values cannot exist unless God exists. One concern is that there might be other naturalistic theories of morality that Craig does not consider. ${ }^{82}$ And there are several such theories out there. He does not consider any of the leading contemporary naturalist theories of moral values, ${ }^{83}$ such as the "Cornell realism", which lays out a metaethical theory where moral facts are constituted not by divine properties but by natural properties, ${ }^{84}$ or neoAristotelian naturalism, which sees goodness as a feature of the will and evil as a kind of natural

on their own, but to build a cumulative case for theism. However, Craig explains that his reason for approaching debates in that way is mainly rhetorical, as well as enabling him to identify several aspects of God (Craig, Reasonable Faith, 190).

${ }^{77}$ Moreland and Craig, Philosophical Foundations for a Christian Worldview, 491.

${ }^{78}$ Craig, Reasonable Faith, 173.

${ }^{79}$ Craig, 174-75; Craig, "The Most Gruesome of Guests," 176-79; Craig, "The Indispensability of Theological MetaEthical Foundations for Morality."

${ }^{80}$ Craig, Reasonable Faith, 177. For a more thorough presentation of this line of thought, see Street, "A Darwinian Dilemma for Realist Theories of Value."

${ }^{81}$ For a recent discussion on such desire-based theories, see Parfit, On What Matters, 2011, chaps. 2-4.

${ }^{82}$ See Miller, Contemporary Metaethics, chaps. 8-9 for some examples of naturalistic theories of ethics.

${ }^{83}$ Lenman, "Moral Naturalism."

${ }^{84}$ This position is associated with the philosophers Richard Boyd, Nicholas Sturgeon, and David Brink, all connected to Cornell University. 
defect. ${ }^{85}$ Another concern is that there might be non-naturalistic theories of morality that Craig does not consider. Craig seem to conflate atheistic theories of ethics with naturalistic theories of ethics, arguing that because objective moral values cannot fit into a naturalistic framework, the truth of objective moral values imply the truth of theism. ${ }^{86}$ This conflation should be avoided. There are non-theistic theories of ethics that label themselves non-naturalistic, theories that does not try to reduce moral facts to natural facts, and these theories are increasing in popularity and support. ${ }^{87}$ As such, they should definitively be taken into account when claiming that objective moral values can only exist if God exists, preferably by discussing leading non-naturalists such as Russ ShaferLandau or Derek Parfit. ${ }^{88}$ So, Craig's moral argument relies on the dismissal of any non-theistic framework making sense of morality. But the dismissal is too hasty, overlooking serious nontheistic attempts to make sense of morality. As such, he has not managed to show that God's existence "follows inevitably" from there being objective moral values and duties. ${ }^{89}$

I have now pointed out two problems in the way Craig practice natural theology, two problems that are made visible by McGrath emphasis on the fact that nature is always interpreted through some framework. First, the moral argument becomes circular as a theistic interpretation is presupposed. Second, the first premise is not successfully established as he neglects other interpretive frameworks. So, Craig has not managed to show that objective moral values provide everyone with a reason to believe in God, nor that this reason is decisive. What he has shown is nothing more than what McGrath says natural theology can show, namely that a theistic framework is consistent with objective moral values, that this framework makes sense of them. Should Craig thereby follow McGrath in abandoning a classical natural theology? In what follows, I will show that if Craig adjusts the way he formulates theistic arguments, he can uphold his understanding of natural theology. The adjustment I propose is somehow inspired by the $13^{\text {th }}$ century theologian Thomas Aquinas.

\section{Changing water into wine}

Thomas Aquinas is known for his use of philosophy in his theological thinking. Aquinas noted that using philosophy in theological thinking might be objected to, as it was by for instance the

\footnotetext{
${ }^{85}$ Foot, Natural Goodness, 4. Others associated with this neo-Aristotelian position are Rosalind Hursthouse, Martha Nussbaum and Judith Jarvis Thomson. There are proponents of the moral argument that covers the main naturalistic theories, such as Ritchie, From Morality to Metaphysics, and the main views on morality, such as Hare, God and Morality.

${ }^{86}$ Craig briefly considers a view he calls "Atheistic Moral Platonism", but his reasons for rejecting this view suffers from the circularity pointed out above, as he is rejecting it because it does not account for imposed duties or accountability. Craig, Reasonable Faith, 178-79.

${ }^{87}$ Fisher, Metaethics, 88. Finlay even describes this as the majority view Finlay, "Normativity, Necessity and Tense," 57.

${ }^{88}$ Ridge, "Moral Non-Naturalism." Other prominent non-naturalists are T. M. Scanlon and Thomas Nagel.

${ }^{89}$ Baggett and Walls have a similar critique of Craig's deductive formulation of the argument. They think he should rather formulate his argument abductively, not because they think the argument fails but because they think an abductive argument has the rhetoric advantage of being more persuasive (Baggett and Walls, God and Cosmos, 64). I, however, think Craig's argument fails.
} 
$13^{\text {th }}$-century theologian Bonaventure. ${ }^{90}$ In Scripture, Aquinas writes, secular wisdom is sometimes compared to water and divine wisdom compared to wine. In Isaiah 1,22, the Israelites are blamed for mixing water with wine. So, in the same way as mixing water with wine would make the wine diluted, one could argue that mixing philosophical thinking with theology would make theology diluted. How does Aquinas respond to such an argument? He says that his theological project does not amount to mixing water with wine, but rather to change water into wine. ${ }^{91}$

What is the project of changing water into wine? It is a project of improvement. The biblical changing of water into wine is a process of improvement, made possible by some divine act. Analogous to this, philosophy may also be improved, and that by the help of theology. So, this is how the metaphor of changing water into wine should be understood, namely as saying that theology can improve philosophical thinking. ${ }^{92}$ It is in this way Aquinas uses the metaphor, namely to illustrate his theological project of showing how Aristotelian philosophy (water) can be strengthened and improved by the use of theological concepts. ${ }^{93} \mathrm{I}$ take it to illustrate an approach to natural theology, namely natural theology as the project of showing how theology can engage with theories in other fields of study, such as philosophy, and improve them. This approach to natural theology is in an important aspect different from that of Moreland and Craig. It does not claim that philosophy is useful for theology, setting out to establish philosophical foundations for a Christian worldview. ${ }^{94}$ Rather, it positions natural theology as a theological project, claiming that theology is useful for philosophy. ${ }^{95}$ This project could be pursued from the position of bare theism, or it could be pursued from the position of a more specified theism such as Christian theism, which is what I do in this article. So, what I will argue now is that an approach to natural theology after the model of changing water into wine will be more successful in establishing theistic arguments than Moreland and Craig's approach.

I have argued that Moreland and Craig's natural theology is exposed to McGrath's critique. Their moral argument starts out from a theistic interpretation of nature, thereby being vulnerable to circularity, and they neglected other possible interpretations of nature, thereby not being able to establish a proof. The way of doing natural theology that I suggest, that of changing water into vine, will not be exposed to these critical remarks. I suggest that the natural theologian should set out to show how theology can improve a certain non-theistic understanding of a natural phenomenon. This approach will not be vulnerable to circularity, since it does not start out from a theistic interpretation of nature. Also, the approach cannot be accused of neglecting other interpretive frameworks as its claims are not global (without God, we cannot make sense of X)

\footnotetext{
${ }^{90}$ Bonaventure writes that "not so much of the water of philosophy should be mixed with the wine of Sacred Scripture that it turn from wine into water" Bonaventure, "Collations on the Six Days" in Kretzmann and Stump, The Cambridge Companion to Aquinas, 58.

91 Aquinas, Commentary on Boethius Q2 art3 a5.

92 Jordan, Rewritten Theology, 169.

93 This is to say that Aquinas is writing as a theologian, not a philosopher. His project is to show how theology illuminates Aristotelian philosophy, not the other way around. Aquinas, Commentary on Boethius Q2 art3 response., Jordan, Rewritten Theology, 158.

${ }_{94}$ Moreland and Craig, Philosophical Foundations for a Christian Worldview, 3.

95 As a theological project, where theology has primacy over philosophy, Barthian worries of establishing a selfsufficient rational route to God apart from revealed theology can be put to rest.
} 
but contextual (with God, we improve this specific understanding of X). So, the natural theologian will start out from a specific interpretation of some natural phenomenon and attempt to demonstrate that the existence of God would improve this specific interpretation, for instance by solving problems facing this specific interpretation. If the existence of God improves the interpretation in question, those holding this interpretation will have a reason to accept the theory that there is a God. Granted, of course, that an improved theory is something that should be pursued. I will now give an example of how such an approach to the moral argument might look like.

\section{An example: Utilitarian water}

One way to structure the moral argument for the existence of God can be found in the work of Sidgwick, a British utilitarianist writing in the $19^{\text {th }}$ century. Sidgwick believed that there were two self-evident methods of ethics. ${ }^{96}$ First, there is the method of egoistic hedonism, namely that each ought to seek his own happiness. ${ }^{97}$ Second, there is the method of universal hedonism, namely that each ought to seek out the happiness of all beings. However, these two methods may conflict, says Sidgwick. They aim at accomplishing different goals, and an act that contributes to the one goal will often stand in the way of the other. Sidgwick saw this conflict as "the profoundest problem" "98 facing utilitarianism. A coherent utilitarianist must somehow solve this conflict, presumably by providing a connection between these two methods. How can such a connection be made? Sidgwick writes that we can make the connection if we believe that there is a God and that there is an afterlife. In that case, God would secure that acting according to universal happiness will be the best way to secure one's own happiness. ${ }^{99}$

I take the structure of Sidgwick's reasoning to be a good example of how one can do natural theology. Sidgwick starts from a specific interpretation of morality, namely utilitarianism. Then he shows that this specific interpretation faces a certain problem, and that this problem is solved in a theistic framework. The structure of this reasoning avoids the dangers described by McGrath above. First, this approach is not presenting a circular argument, as it starts out from a nontheistic interpretation of moral values and not a theistic interpretation. Second, it cannot be accused of neglecting other interpretive frameworks as its aim is to be contextual, engaging with one specific view of ethics. And third, it is not an attempt to establish a proof; not an attempt to give everyone a decisive reason to accept the theory that God exists. Rather, it is an approach that is showing how theology can improve a specific theory of ethics, giving those who hold this theory a reason - not a decisive reason, but a reason nonetheless - to take advantage of theological concepts. To use the imagery of Aquinas, one can say that Sidgwick is turning utilitarian water into wine.

\footnotetext{
96 Sidgwick, The Methods of Ethics, 7-8, 411.

${ }^{97}$ Happiness is here understood as the greatest possible surplus of pleasure over pain. Sidgwick, 413.

98 Sidgwick, 386 n.4.

${ }^{99}$ Sidgwick, 496-509 especially p.505. A similar argument is found in Kant, Critique of Practical Reason, bk. 2, chapter $2, \mathrm{~V}$.
} 
One might wonder if Sidgwick's argument, which is over a hundred years old, still has any merit in the contemporary moral discourse. Interestingly enough, the conflict between self-interest and universal happiness is still present in the literature. Both Derek Parfit and Peter Singer argues that it is a serious problem as the conflict implies that moral concerns do not outweigh prudential concern, which would undermine morality altogether. ${ }^{100}$ So, it is still relevant to argue, as some has done, that this problem can be solvent in a theistic framework. ${ }^{101}$ There might be several theological resources available to do so. One might build on Sidgwick's suggestion, as C. Stephen Layman does, arguing that the problem is solved by appeal to a Christian notion of the afterlife: to act immorally is to $\sin$, to $\sin$ is to alienate oneself from God, so since alienation from eternal life with God is not in one's long-term interests, it will not be in one's interest to let present prudential concerns outweigh moral concerns. ${ }^{102}$ Alternatively, one might point to notions of providence and vocation found in the Christian tradition, as John Hare does, arguing that God has a route for each one of us towards the final good, thereby coordinating the routes of each person so that seeking one's own good will not conflict with universal happiness. ${ }^{103}$ Either way, there are theological recourses available to solve a utilitarian problem, which gives the utilitarian a reason to adopt a theological framework.

Now, the idea behind this way of doing natural theology is the claim that theism can improve certain theories, that it can make them better. However, the criteria by which to identify a theory as better might be contested. This is evident in the literature on inference to the best explanation, where the criteria for evaluating explanations are not completely agreed upon. ${ }^{104}$ As McGrath noted, different frameworks might employ different sets of criteria for evaluation. Therefore, two things should be kept in mind if one is to do natural theology in a non-contentious way. First, one should not evaluate an explanation of a natural phenomenon, done within a certain framework, by criteria that are alien to the framework in question. Instead, one should set out to show that theological concepts would make better sense of the phenomenon given criteria familiar to this framework. This is what Sidgwick does. He demonstrates how theological concepts can improve utilitarianism, not by theological standards, but by standards familiar to utilitarianism. ${ }^{105}$

\footnotetext{
100 Parfit, On What Matters, 2011, chap. 6; Lazari-Radek and Singer, The Point of View of the Universe, chap. 6.

101 Baggett and Walls, God and Cosmos, 257-69.

102 Layman, "God and the Moral Order." See Ward, Morality, Autonomy, and God, chap. 8 for an argument that this view does not entail that the moral life becomes a means for self-interest. Some might be worried that belief in an afterlife, where God ensures that all shall be well, warrants social and political passivity. Layman's suggestion avoids the worry that, since individual destiny in the afterlife will partly depend upon how one tries to live one's life. See also Zagzebski, Divine Motivation Theory, chap. 6, who argues that what is best for me, namely union with Christ, involves imitating Christ, which arguably implies acting on the needs of the poor and oppressed (Luke 4).

${ }^{103}$ Hare, God and Morality, 245-48, 273-74, 287-88.

104 This is noted by Thagard, "The Best Explanation," 76; McGrath, The Open Secret, 235-36. Lipton lists some criteria that are commonly cited, but the sources he uses to create this list disagrees for instance on what it is for an explanation to be simple, and whether simplicity is an explanatory virtue at all. Peter. Lipton, Inference to the Best Explanation, 122.

${ }^{105}$ Another viable way to show that theological concepts improve a theory or a framework would be to propose some criteria by which all theories and frameworks can be compared. See for instance Søvik, "A Theoretical Framework for Talking Seriously About God.”
} 
One might raise a concern at this point, namely that if the proposed theistic improvement is evaluated within the framework in question, it is likely that the proposed improvement will not be seen as an improvement at all. The cost of the added theistic hypothesis can, by a non-theist, be seen as too high. One thing that raises the cost could be that the addition of a new entity, namely God, makes the theory less simple. To this, it should be said that while the literature on inference to the best explanation usually lists simplicity as an explanatory virtue, it does not put simplicity above explanatory power or scope. It will be very controversial to prefer the simpler theory that lacks scope, that leaves problems unsolved, to the more complex theory that solves the problems. It is only when two theories give an equally good account of the thing to be explained that simplicity becomes a factor. ${ }^{106}$ Another thing that could raise the cost of the theistic hypothesis is that the God-hypothesis might fit poorly with other things one believes. Take for instance Parfit, who recognise that the notion of God might actually solve some problems in his metaethical theory, but rejects theism because it fits poorly with other things he believes, namely that there exists pointless evil. ${ }^{107}$ To this, it should be said that while there might be features of the world that give a reason to reject the theism, such as pointless evil, that does not change the fact that other features might give a reason to accept theism. So, just as a theist who takes the overall balance of evidence to support theism - should recognise that there are some features that provide reason against theism, the non-theist should recognise that even though he thinks the overall balance of evidence does not support theism, there might be some reasons that count in its favour. ${ }^{108}$

A second thing to have in mind is that one should not make use of ad hoc explanations. To see why this needs to be avoided, consider the fact that carbon is a key component of all life known on Earth. To explain this fact, one could propose the theory that a carbon-preferring God created life. Carbon-based life form would support this theory, which would make the fact that life on earth is carbon-based give us a reason accept theism. However, this seems counterintuitive. It is counterintuitive because the explanation is ad hoc, it is designed to account for only this phenomenon. If proposing such explanations was an accepted practice, one could propose a theistic framework with all sorts of ad hoc components that would perfectly explain everything. Now, a hypothesis will qualify as non-ad hoc if there are either independent motivations for holding the hypothesis apart from it serving as an explanation of the phenomenon in question, or if the hypothesis has been widely advocated prior to the confirming evidence. ${ }^{109}$ Sidgwick's argument does not amount to an ad hoc-explanation as the notions of a good God, providence, vocation, and afterlife are widely advocated in the Christian tradition.

\footnotetext{
106 Hempel, Philosophy of Natural Science, 320; Douven, “Abduction,” pt. 1.2. For an argument that simplicity is not a good-making feature of an explanation, see W. H. Newton-Smith, The Rationality of Science, 230. Others understand simplicity not to be about few entities but few entities that are independent of each other, that lacks connections or are ad hoc. See Lipton, Inference to the Best Explanation, 139; Friedman, "Explanation and Scientific Understanding."

107 Parfit, On What Matters, 2011, 493, 498, 567.

${ }^{108}$ For a theist who holds this view, see Swinburne, The Existence of God, 266.

${ }^{109}$ Collins, "The Teleological Argument," 206.
} 


\section{Lower ambitions, higher achievements}

Seeing natural theology as the turning water into wine, namely the project of improving a specific theory, is a less ambitious project than the project of classical natural theology. It is less ambitious in the sense that the project of improvement does not attempt to provide a decisive reason for accepting the conclusion that God exists. An argument of improvement is not a deductive argument, not the kind of argument where the conclusion that God exists "follows inevitably". ${ }^{110}$ It is rather an abductive argument, resulting in the more modest conclusion that including God in the theory give us a better account of a certain phenomenon. Now, an abductive argument does not provide a decisive reason, not a reason that outweighs all other reasons so that the only rational thing to do is to accept the conclusion. As such, an argument of improvement does not force the audience to accept the theistic hypothesis. Nevertheless, a reason is provided.

Moreover, natural theology as the project of improvement is less ambitious as it does not attempt to formulate arguments that provide everyone with a reason for accepting the conclusion. It is more contextual, aiming to give someone a reason. It takes seriously the notion that nature is always seen through a certain framework, and does not aim at presenting an argument that is valid in all frameworks. By showing how a specific view of some natural phenomenon is improved in a theistic framework, those who hold this view will have a reason to accept theism. It is interesting to see that this line of reasoning is implicit in the work of prominent theistic ethicists such as Linda Zagzebski and Robert Adams. Both of them argue that a certain view of morality makes better sense with God than without, and they seem to take this as a reason for including God in the moral theory. Zagzebski spends the first half of her book laying out a kind of virtue ethics, and then shows how this theory is improved in a Christian framework. ${ }^{111}$ Adams presents a theory of moral obligations as constituted by social requirements, and then argues that the theory has "salient defects" that are fixed in a Christian framework. ${ }^{12}$ So, there may be several different moral arguments, all framework-specific, aimed at different views of morality.

Natural theology as the project of improvement is not only a less ambitious project, it is also less demanding. While it is a formidable task to argue that only way to make sense of a certain phenomenon - for instance morality - is by appeal to God, it is a more manageable task to argue that a certain theory makes better sense of the phenomenon with God than without. For once, it is less demanding since one does not have to exclude all other alternatives. For instance, when arguing that theology improve a certain theory, one does not have to argue that this is the only way of improving this theory. Sidgwick's argument is an example of this. He shows that theology can improve utilitarianism, but he does not show that theology is the only way to do so. For all he knows, there might be other recourses that do the same work. But until such recourses are found, this moral theory makes better sense with God than without. Second, it is less demanding since one does not have to argue that one has found the best way to make sense of some phenomenon, the one view that beats all alternative views. All that is needed is to show that a

\footnotetext{
${ }^{110}$ Craig, Reasonable Faith, 52, 195.

111 Zagzebski, Divine Motivation Theory, 183. See also Zagzebski, "Does Ethics Need God?”

112 Adams, Finite and Infinite Goods, 249-50.
} 
specific theory makes better sense with God than without, which gives those holding that theory a reason to accept theism. For example, while Sidgwick shows that theology can improve utilitarianism, he does not show that the best way of making sense of morality - given a theological framework - amounts to utilitarianism. Given a theological framework, there might be an even better way of making sense of morality.

Now, while the project of turning water into wine has lower ambitions than classical natural theology, its achievements are higher. McGrath's critique has shown that classical natural theology does not achieve very much. It attempts to show that theism is the only view that makes sense of certain phenomenon, but the attempt fails. The project of turning water into wine is not vulnerable to this critique. So, while this project does not give everyone a decisive reason to accept theism, it does give someone a reason. As such, it has managed to achieve what Moreland and Craig hold that natural theology is all about, namely to "provide warrant for belief in God's existence". 113

Also, this approach to natural theology has higher achievements than McGrath's natural theology. First, to whom does natural theology give reason to accept a Christian framework? In McGrath's natural theology, reasons come after faith, as a retrospective validation. ${ }^{114}$ As such, his natural theology provides reasons for those who already believe. The natural theology of improvement, on the other hand, provides reasons for non-believers as well. Second, does natural theology provide many reasons or just one? McGrath holds that natural theology provides a single reason for accepting Christian theism. He takes theistic arguments based on single aspects of reality to be insignificant, while a cumulative case showing how a Christian interpretation makes sense of reality as a whole is richly suggestive. As such, this single reason is a comprehensive one: it is based on the whole of reality, and it gives a reason to accept the whole of Christian Theology. ${ }^{115}$ Now, natural theology as a project of improvement might of course recognise the force of a cumulative argument. One could make a comprehensive cumulative case as McGrath suggests, or one could make a cumulative case concerning just one aspect of reality, combining for instance different moral arguments. ${ }^{116}$ However, one does not have to make a cumulative case in order to have a forceful argument. Arguments of improvement are numerous, based on many different parts of reality, and they are not insignificant.

\section{Conclusion}

While McGrath has delivered an accurate critique of a usual way of doing classical natural theology, one does not have to abandon the sort of natural theology that seeks to provide

\footnotetext{
113 Craig and Moreland, The Blackwell Companion to Natural Theology, ix.

114 McGrath, The Open Secret, 16.

115 As Holder points out, there is much at stake here. One is asked to accept the whole theological package - trinity, virgin birth eschatology, and so on. The theological system must be swallowed as a whole or not at all: "Like it or lump it!" Holder, The Heavens Declare, 202.

${ }^{116}$ C. Stephen Evans suggests this. He writes that while each moral argument may be rejected, this does not mean that the arguments have no force. They can be combined, and possibly lead to the interesting conclusion that atheism required one to reject moral realism altogether. Evans, "Moral Arguments for the Existence of God," pt. 7.
} 
arguments for the existence of God. By doing natural theology after the model of changing water into wine, one can provide arguments for the existence of God in a way that is not vulnerable to McGrath's critique. This way of doing natural theology is not as ambitious as Moreland and Craig's project, and not as modest as McGrath's. Moreland and Craig seem to bite off more than they can chew, trying to provide everyone with a decisive reason to accept theism. McGrath seems to bite off too little, seeing natural theology as an internal confirmation of a Christian framework, providing reasons for the already converted. The way of doing natural theology that I propose does not aspire to give everyone a reason to accept the theory that God exists, but it does manage to give someone such a reason, and not only the already converted. By doing natural theology in this way, namely by showing how theology may improve a certain non-theistic understanding of a natural phenomenon, one can assert, contra McGrath, ${ }^{117}$ that nature provides a gateway to a theistic framework. Or rather, one can assert that nature provides many gateways to a theistic framework. Just as there are numerous ways of seeing nature, there are numerous waters to be transformed into wine. When Aquinas explains his use of philosophy in his theological thinking, he writes that "we take captive every thought to make it obedient to Christ." 118 Aquinas took the thought of Aristotelian philosophy, Sidgwick took the thought of utilitarianism. These thoughts, and many more, can be made to serve a theological end by showing how they are improved in a theistic framework. ${ }^{119}$

\footnotetext{
117 McGrath, The Open Secret, 5.

118 Aquinas, Commentary on Boethius Q2 art3 response. Aquinas quotes 2 Cor. 10:5.

119 Thanks to Einar Duenger Bohn, Jan-Olav Henriksen, Andrew Moore, Pål Repstad, Atle Ottesen Søvik, and two very helpful anonymous referees for comments and discussions.
} 


\section{Bibliography}

Adams, Robert Merrihew. Finite and Infinite Goods: A Framework for Ethics. Oxford: Oxford University Press, 1999.

Alister E. McGrath. The Science of God: An Introduction to Scientific Theology. T\&T Clark, 2004. Anscombe, G. E. M. “Modern Moral Philosophy.” Philosopby 33, no. 124 (1958): 1-19.

Aquinas, Thomas. Commentary on Boetbius. Translated by Armand Maurer. The Collected Works of St. Thomas Aquinas. Leiden: Brill, 1987.

Baggett, David, and Jerry L. Walls. God and Cosmos: Moral Truth and Human Meaning. New York: Oxford University Press, 2016.

. Good God: The Theistic Foundations of Morality. Oxford: Oxford University Press, 2011.

Barth, Karl. Church Dogmatics. Vol. IV.1. Peabody, MA.: Hendrickson Publishers, 1956.

—. Church Dogmatics. Vol. II.1. Peabody, MA.: Hendrickson Publishers, 1957. Church Dogmatics. Vol. III.2. Peabody, MA.: Hendrickson Publishers, 1960.

Chignell, Andrew, and Derk Pereboom. "Natural Theology and Natural Religion." In The Stanford Encyclopedia of Philosophy, edited by Edward N. Zalta, Fall 2015. Accessed November 15, 2016. http://plato.stanford.edu/archives/fall2015/entries/natural-theology/.

Coakley, Sarah. Stories of Evolution, Stories of Sacrifice. Gifford Lectures: Sacrifice Regained:

Evolution, Cooperation and God. University of Aberdeen, 2012. accessed 11 Novermber 2016. http://www.giffordlectures.org/lectures/sacrifice-regained-evolution-cooperationand-god. Accessed 27 October 2016.

Collins, Robin. "The Teleological Argument." In The Blackwell Companion to Natural Theology, edited by William Lane Craig and James Porter Moreland, 202-82. Chichester, U.K.: Wiley-Blackwell, 2009.

Craig, William Lane. Reasonable Faith. Rev. Wheaton, IL.: Crossway Books, 1994. . "The Indispensability of Theological Meta-Ethical Foundations for Morality." Foundations, no. 5 (1997): 9-12.

. "The Most Gruesome of Guests." In Is Goodness Without God Good Enough? : A Debate on Faith, Secularism, and Ethics, edited by Nathan King and Robert Garcia, 167-88. Lanham, MD: Rowman \& Littlefield Publishers, 2008.

Craig, William Lane, and James Porter Moreland. The Blackwell Companion to Natural Theology. MA: Wiley-Blackwell, 2009.

Craig, William Lane, and Walter Sinnott-Armstrong. God?: A Debate between a Christian and an Atheist. 1 edition. Oxford ; New York: Oxford University Press, 2004.

Crossman, R. H. S. The God That Failed. New York ; Chichester: Columbia University Press, 2001. Douven, Igor. "Abduction." In The Stanford Encyclopedia of Philosophy, edited by Edward N. Zalta, Spring 2011. Accessed April 12, 2016. http://plato.stanford.edu/archives/spr2011/entries/abduction/.

Enoch, David. Taking Morality Seriously. Oxford: Oxford University Press, 2011.

Evans, C. Stephen. "Moral Arguments for the Existence of God." In The Stanford Encyclopedia of Philosophy, edited by Edward N. Zalta, Summer 2014. Accessed May 11, 2016. http://plato.stanford.edu/archives/sum2014/entries/moral-arguments-god/. Accessed 5 November 2016.

- Natural Signs and Knowledge of God: A New Look at Theistic Arguments. Reprint edition. Oxford: Oxford University Press, 2012.

Finlay, Stephen. "Normativity, Necessity and Tense: A Recipe for Homebaked Normativity." In Oxford Studies in Metaethics, Vol. 5, edited by Russ Shafer-Landau, 57-85. Oxford University Press, 2010.

Fisher, Andrew. Metaethics: An Introduction. Hoboken: Taylor and Francis, 2014.

Foot, Philippa. Natural Goodness. 1 edition. Oxford; New York: Clarendon Press, 2003. 
Pre-proof. Final version: https://doi.org/10.1080/0039338X.2018.1446356

Friedman, Michael. "Explanation and Scientific Understanding." Journal of Philosophy 71, no. 1 (1974): 5-19.

Hare, John E. God and Morality. MA: Blackwell, 2009.

Hempel, Carl. Philosophy of Natural Science. Englewood Cliffs: Prentice Hall, 1966.

Holder, Rodney. The Heavens Declare: Natural Theology and the Legacy of Karl Barth. West Conshohocken: Templeton Press, 2012.

John Polkinghorne. "Where Is Natural Theology Today?” Science and Christian Belief 18 (2006): 169-79.

Jordan, Mark D. Rewritten Theology: Aquinas After His Readers. 1 edition. Malden, MA ; Oxford: Wiley-Blackwell, 2005.

Kant, Immanuel. Critique of Practical Reason. Edited by Mary J. Gregor. Cambridge Texts in the History of Philosophy. Cambridge, U.K: Cambridge University Press, 1997.

Kretzmann, Norman, and Eleonore Stump. The Cambridge Companion to Aquinas. Cambridge University Press, 1993.

Layman, Stephan C. "God and the Moral Order." Faith and Philosophy 19, no. 3 (2002): 304-16.

Lazari-Radek, Katarzyna de, and Peter Singer. The Point of View of the Universe: Sidgwick and Contemporary Ethics. Oxford: Oxford University Press, 2016.

Lenman, James. "Moral Naturalism." In The Stanford Encyclopedia of Philosophy, edited by Edward N. Zalta, Spring 2014., 2016. http://plato.stanford.edu/archives/spr2014/entries/naturalism-moral/.

Lipton, Peter. Inference to the Best Explanation. 2nd ed. International Library of Philosophy. London: Routledge, 2004.

MacIntyre, Alasdair. Whose Justice? Which Rationality? London: Gerald Duckworth \& Co., 1988.

McGrath, Alister E. A Fine-Tuned Universe: The Quest for God in Science and Theology. Louisville, Ky: Westminster John Knox Press, 2009.

. Enriching Our Vision of Reality: Theology and the Natural Sciences in Dialogue. London: SPCK, 2016.

. Re-Imagining Nature: The Promise of a Christian Natural Theology. Chichester, West Sussex: Wiley Blackwell, 2017.

. Scientific Theology, Volume 2. London: T\&T Clark, 2006.

- "The Natural Sciences and Apologetics." In Imaginative Apologetics: Theology, Philosophy and the Catholic Tradition, edited by Andrew Davison, 142-58. SCM Press, 2011.

. The Open Secret: A New Vision for Natural Theology. Malden, MA: Blackwell Publishing, 2009.

Miller, Alexander. Contemporary Metaethics - An Introduction. Edited by Second Edition. Cambridge: Polity Press, 2013.

Moreland, James Porter, and William Lane Craig. Philosophical Foundations for a Christian Worldview. Downers Grove, Ill.: InterVarsity Press, 2003.

Morriston, Wes. "God and the Ontological Foundation of Morality." Religious Studies 48, no. 1 (2012): 15-34.

Nagel, Thomas. The View From Nowhere. New York: Oxford University Press, 1986.

Parfit, Derek. On What Matters, Vol. 1. Edited by Samuel Scheffler. Oxford: Oxford University Press, 2011.

. On What Matters, Vol. 2. Edited by Samuel Scheffler. Oxford: Oxford University Press, 2011.

Peter. Lipton. Inference to the Best Explanation. 2nd ed. International Library of Philosophy. Taylor and Francis, 2003.

Ridge, Michael. "Moral Non-Naturalism." In The Stanford Encyclopedia of Philosophy, edited by Edward N. Zalta, Fall 2014., 2016.

http://plato.stanford.edu/archives/fall2014/entries/moral-non-naturalism/. 
Pre-proof. Final version: https://doi.org/10.1080/0039338X.2018.1446356

Ritchie, Angus. From Morality to Metaphysics. Oxford: Oxford university press, 2012.

Sidgwick, Henry. The Methods of Ethics. Ind.: Hackett, 1981.

Søvik, Atle Ottesen. “A Theoretical Framework for Talking Seriously About God.” In Talking Seriously about God. Nordic Studies in Theology, edited by Atle Ottesen Søvik and Asle Eikrem, 55-76. Wien: LIT Verlag, 2016.

Søvik, Atle Ottesen, and Asle Eikrem, eds. Talking Seriously About God: Philosophy of Religion in the Dispute Between Theism and Atheism. Wien: LIT Verlag, 2016.

Street, Sharon. "A Darwinian Dilemma for Realist Theories of Value." Philosophical Studies 127, no. 1 (2006): 109-66.

Swinburne, Richard. The Existence of God. 2nd ed. Oxford: Clarendon Press, 2004.

Thagard, Paul R. "The Best Explanation: Criteria for Theory Choice." Journal of Philosopby 75, no. 2 (1978): 76-92.

W. H. Newton-Smith. The Rationality of Science. International Library of Philosophy. London: Routledge, 1990.

Ward, Keith. Morality, Autonomy, and God. London: Oneworld, 2013.

Zagzebski, Linda. "Does Ethics Need God?” Faith and Philosophy 4, no. 3 (1987): 294-303.

Zagzebski, Linda Trinkaus. Divine Motivation Theory. Cambridge University Press, 2004. 